\title{
Technical Information
}

\section{Summaries of Toxicity Studies on Chloridazon}

\author{
Registration Department, Agricultural Chemicals Division, BASF Japan Ltd.
}

(Received February 20, 1992)

\section{DESCRIPTION OF THE TEST COMPOUND}

Chloridazon is a chemical developed by BASF Aktiengesellschaft in early 1960s. Through a number of trials in which its biological activity was tested, it has been confirmed that Chloridazon is an effective herbicide for upland field, and has been mainly used for weeding in sugar beet cultivation. This article provides a toxicological feature of Chloridazon obtained from toxicological studies with the technical grade (hereafter as CHLORIDAZON TECH), and the wettable powder formulation containing 65\% Chloridazon (hereafter as PYRAMIN WP).

The chemical structure and physical properties of Chloridazon are given below:

Common name: Chloridazon (ISO) PAC (Japan)

Chemical name: 1-Phenyl-4-amino-5-chloropyridazon-(6)

Structural formula:

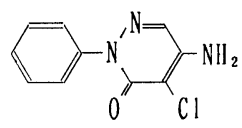

Molecular formula: $\mathrm{C}_{10} \mathrm{H}_{8} \mathrm{ClN}_{3} \mathrm{O}$

Molecular weight: 221.6

Appearance: Brownish solid

Melting point: $205-206^{\circ} \mathrm{C}$

Vapor pressure: $\quad<1 \times 10^{-7} \mathrm{mbar}\left(56.5^{\circ} \mathrm{C}\right)$

Solubility $\left(\mathrm{g} / \mathrm{l}\right.$ solvent at $\left.20^{\circ} \mathrm{C}\right)$ : Water 0.4 , methyl alcohol 24, acetone 22, ethyl acetate 5.4 , chloroform 3.1 , benzene 0.6 , ether 0.5 , cyclohexane $<0.08$

Partition coefficient ( $n$-octanol/water): 1.26

Stability: No decomposition at $50^{\circ} \mathrm{C}$ for 3 years in an unopened original package. No decomposition in the respective solutions of $0.1 \mathrm{~N} \mathrm{NaOH}$ and $0.1 \mathrm{~N} \mathrm{HCl}$ for 24 hours.

\section{ACUTE TOXICITY}

Table 1 shows results of acute toxicity studies with CHLORIDAZON TECH and PYRAMIN WP at different routes of administration.

In these tests, dosing of the respective test substances caused non-specific signs of toxicity after administration via different routes.

\section{LOCAL TOLERANCE AND SENSITIZATION}

Instillation of CHLORIDAZON TECH (about $50 \mathrm{mg} / \mathrm{eye}$ ) into the conjunctival sac of the right eyelid of rabbits caused slight irritant effects of the conjunctiva.

(Department of Toxicology, BASF, 1977)

PYRAMIN WP (about $50 \mathrm{mg} / \mathrm{eye}$ ) was tested in the same manner, and caused slight erythema that regressed within 8 days.

(Department of Toxicology, BASF, 1975)

The local tolerance was tested with CHLORIDAZON TECH on the intact and abraded dorsal skin of rabbits by application for 24 hours under an occlusive dressing. Using about $0.5 \mathrm{~g} /$ patch, slight erythema was observed on both intact and abraded dorsal skin that subsided within 3 and 8 days respectively.

(Department of Toxicology, BASF, 1977)

PYRAMIN WP (about $0.5 \mathrm{~g} /$ patch) was tested in the same manner, and caused slight to moderate erythema on the intact skin 24 hours after application which were still present after 72 hours in milder form. On the abraded dorsal skin, well-defined to moderate erythema was observed which were still present after 72 hours.

(Department of Toxicology, BASF, 1975) No sensitizing potential was obsərved 


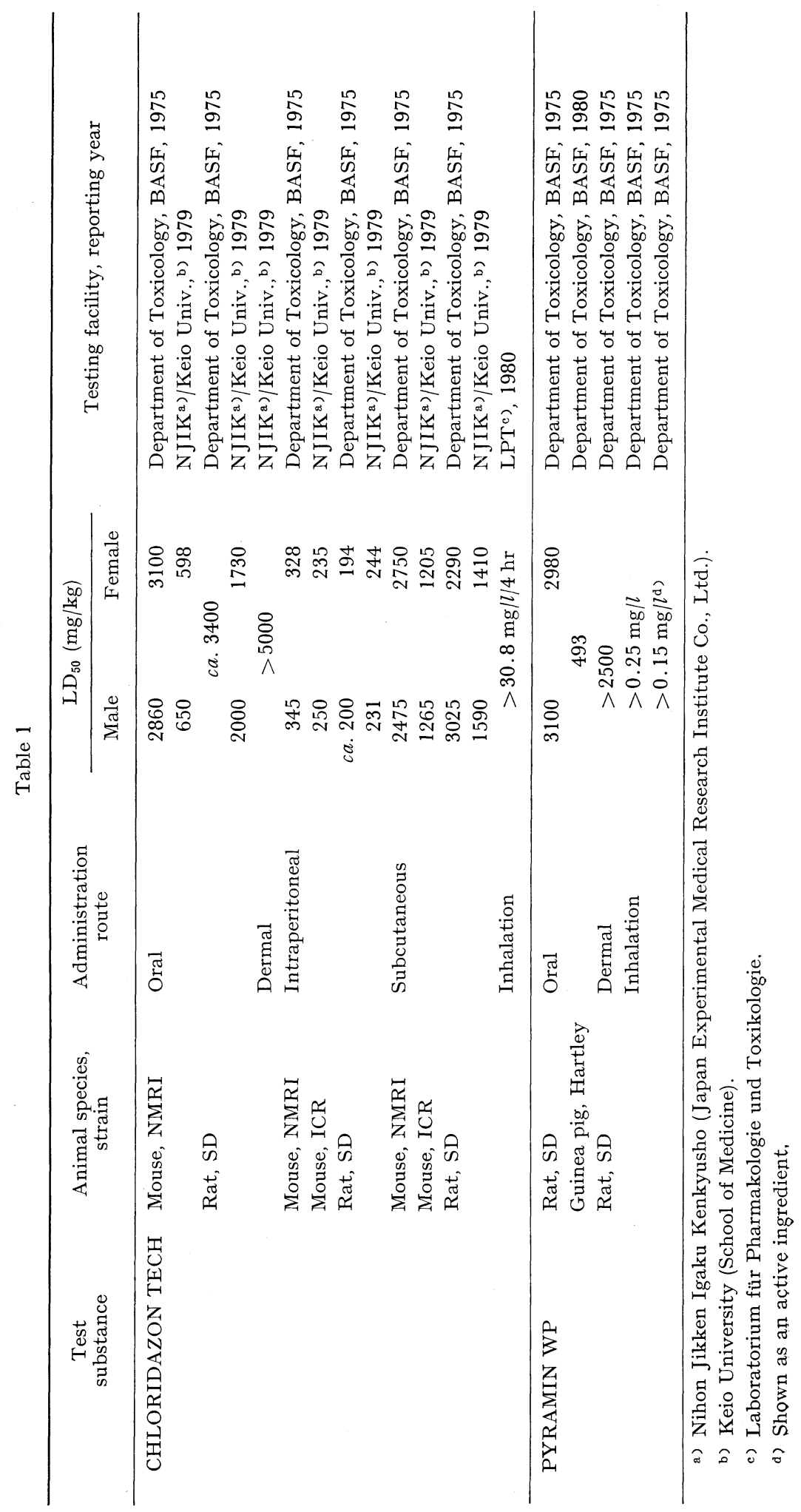


when a formulation containing $80 \%$ CHLORIDAZON TECH was tested based on a method like Buehler test for its skin sensitizing effect in guinea pigs.

(Department of Toxicology, BASF, 1967)

\section{SUBCHRONIC TOXICITY STUDIES}

In a 13-week study with SD rats, CHLORIDAZON TECH was administered via the diet at dose levels of $0,300,1200,4800$ and 19,200 ppm (reduced to 9600 ppm after 5-week administration) to 20 male/20 female rats (control group and high dose groups) and 15 male/ 15 female rats (all other groups).

Dose levels of $1200 \mathrm{ppm}$ or higher caused some effects that would be attributable to the test substance, such as reduced food consumption, lower food efficiency, lower values of erythrocytic parameters, higher values of SGPT or SAP, increased liver weight, increase of thyroid weight, enlargement of hepatocytes in centrilobular areas, decrease in glycogen content of periportal hepatocytes, etc., whereas no changes were observed at $300 \mathrm{ppm}$. Thus, the NOEL is $300 \mathrm{ppm}(=20.7 \mathrm{mg} / \mathrm{kg}$ b.w. in males and $23.5 \mathrm{mg} / \mathrm{kg}$ b.w. in females).

(Huntingdon Research Centre, 1975)

\section{CHRONIC TOXICITY AND ONCOGENICITY}

In a combined chronic and carcinogenicity study, CHLORIDAZON TECH was administered via the diet at dose levels of $0,150,450$, 1350 and $4050 \mathrm{ppm}$ to $40 \mathrm{SD}$ rats per sex and dose over a period of 104 weeks.

The only treatment-related findings at the high dose level were: an increase in severity and/or incidence of muscle atrophy in the scapular muscle or in the thigh muscle in males and females. Though higher organ weight with liver, kidney and thyroid in males and/or females were noted at the highest dose (4050 ppm), histopathological examination did not reveal any associated changes at the cellular level. The NOEL is $150 \mathrm{ppm}(=5.41$ $\mathrm{mg} / \mathrm{kg}$ b.w. in males and $6.70 \mathrm{mg} / \mathrm{kg}$ b.w. in females). There was no indication of a carcinogenic potential.

(Huntingdon Research Centre, 1977)

In another combined chronic and carcinogenicity study, 68 CFLP mice per sex and dose were administered CHLORIDAZON TECH via the diet at dose levels of $0,160,500,4000$ and $20,000 \mathrm{ppm}$. The administration period for male animals receiving $0,160,500$ or 4000 ppm was 96 weeks, and 86 weeks for 20,000 $\mathrm{ppm}$, whereas the administration period for females receiving $0,500,4000$ or $20,000 \mathrm{ppm}$ was 92 weeks and 83 weeks for $160 \mathrm{ppm}$.

Effects observed at $4000 \mathrm{ppm}$ were increased liver weight. At 20,000 ppm, effects such as granular eosinophilic cytoplasm in hepatocytes with or without enlargement, higher SGPT levels, small increase of spleen and ovary weights were noted. Some effects were also noted on growth rate, food consumption, food efficiency and water intake at 20,000 ppm. No tumorgenic potential could be attributed to the test substance. The NOEL for chronic effects is $500 \mathrm{ppm}(=44 \mathrm{mg} / \mathrm{kg} \mathrm{b.w}$ in males and $48 \mathrm{mg} / \mathrm{kg}$ b.w. in females).

(Huntingdon Research Centre, 1977)

\section{TERATOGENICITY AND REPRODUCTION STUDY}

The effect on the reproduction was tested with SD rats in a three-generation study using one litter in each generation. Twenty animals per sex and dose were administered CHLORIDAZON TECH at dose levels of $0,150,450$ and $1350 \mathrm{ppm}$ via the diet. $\mathrm{F}_{0}, \mathrm{~F}_{1}$ and $\mathrm{F}_{2}$ animals were mated to produce a litter $\left(F_{1 a}\right.$, $\mathrm{F}_{2 \mathrm{a}}$ and $\mathrm{F}_{3 \mathrm{a}}$ ). From $\mathrm{F}_{1 \mathrm{a}}$ and $\mathrm{F}_{2 \mathrm{a}}, 20$ animals per sex and dose were selected to form the $F_{1}$ and $\mathrm{F}_{2}$ parental generation respectively. After weaning, they were fed the same feed as their parents until mating for producing the $\mathrm{F}_{2 \mathrm{a}}$ and $\mathrm{F}_{3 \mathrm{a}}$ litter. $\mathrm{F}_{0}$ animals and surplus pups of $\mathrm{F}_{1 \mathrm{a}}$ were sacrificed and examined macroscopically. Parental animals of $F_{1 a}$ and $F_{2 a}$ were sacrificed and examined macroscopically for abnormalities as well as surplus pups of $F_{2 a}$ and all $\mathrm{F}_{3 \mathrm{a}}$ pups.

There were no clinical signs of toxicity and no deaths attributable to the test substance among the parent animals. Furthermore there were no substance-related effects on food consumption or body weight gain in all three generations. Males of $F_{0}$ and $F_{1}$ tended to show lower food consumption at higher doses, 450 and/or $1350 \mathrm{ppm}$. Pregnancy rate and the duration of gestation were unaffected by 
the test substance. Litter parameters such as litter loss, litter size, litter weight, mean pup weight and pup mortality rates from birth through lactation, were not affected by the test substance over the three generations. Based on the results of this study, it can be concluded that Chloridazon does not affect reproduction and has no teratogenic potential.

(Huntingdon Research Centre, 1977)

In a study carried out with NMRI mice, Chloridazon was tested for pre-, peri- and postnatal toxicity. Twenty one animals were administered CHLORIDAZON TECH via the diet at dose levels of 0,5000 and 10,000 ppm from day 0 of pregnancy to day 18 post coitum. Part of the animals were sacrificed on day 18 post coitum, and fetuses were removed by Cesarian section. Additional 10 animals were administered the given doses up to day 18 post coitum, followed by a ground commercial diet (Altromin-R) without the test substance up to day 21 post partum. Further 10 animals were administered the test substance via the diet from day 0 of pregnancy to day 21 post partum. The latter 2 groups each were allowed to litter spontaneously and to rear the young to day 21 post partum. A swimming test was carried out before the young and adult animals were sacrificed on day 22 post partum.

No adverse effects were observed in clinical examination. No substance-related changes could be observed in any of the parameters investigated. Adult animals showed no signs of intoxication nor adverse effects on food consumption and body weight gain. The administration of the test substance did not alter the littering behavior, size of litter and date of littering. Postmortem examination of all adult and young animals revealed no macroscopic pathological changes. No substance-related changes especially in the nature and number of malformations, retardations and variations were found. Under the test conditions chosen, Chloridazon has no teratogenic properties.

(Department of Toxicology, BASF, 1975)

\section{MUTAGENICITY STUDIES}

DNA repair test was investigated in the in vitro Rec-assay using Bacillus subtilis strains $\mathrm{H} 17\left(\mathrm{Rec}^{+}\right)$and $\mathrm{M} 45$ (Rec-). CHLORIDAZON
TECH, dissolved in dimethylsulfoxide, was tested at dose levels of 20 to $2000 \mu \mathrm{g} /$ disk.

At all levels, no indication for DNA damage was observed.

(The Institute of

Environmental Toxicology, 1976)

Genetic damage resulting from gene mutation was investigated in the Ames test using Salmonella typhimurium, strains TA 98, TA 100, TA 1535, TA 1537 and TA 1538, and Escherichia coli, strain WP2 hcr-, with and without metabolic activation (rat liver homogenate). CHLORIDAZON TECH, dissolved in dimethylsulfoxide, was tested at dose levels between 10 and $3000 \mu \mathrm{g} /$ plate without metabolic activation, and at dose levels of 10 and $1000 \mu \mathrm{g} /$ plate with metabolic activation.

No mutagenic effect was observed.

(The Institute of Environmental Toxicology, 1976)

The host-mediated assay was conducted with ICR mice. Six males/dose were orally administered doses of 50 and $100 \mathrm{mg} / \mathrm{kg}$ b.w., during a period of 24 hours. After the 2nd administration, a suspension of Salmonella typhimurium G 46 (his ${ }^{-}$) was given intraperitoneally. Three hours after the treatments, the animals were sacrificed and the peritoneal fluid was transferred to an agar plate for the detection of revertant bacterial cells.

No mutagenic activity was observed.

(The Institute of Environmental Toxicology, 1976)

CHLORIDAZON TECH was tested for the ability to induce chromosomal aberrations in human lymphocytes in an in vitro cytogenetic assay. The dose levels tested were 2.0, 4.0 and $5.0 \mu \mathrm{g} / \mathrm{ml}$ without metabolic activation, and 1 , 2 and $4 \mu \mathrm{g} / \mathrm{ml}$ with metabolic activation (rat liver homogenate).

Under the experimental conditions of this study, the test substance did not lead to an increase in the number of aberrant metaphases neither without nor with metabolic activation. Therefore Chloridazon is considered not to be chromosome-damaging.

(Department of Toxicology, BASF, 1988)

\section{GENERAL PHARMACOLOGY}

1. Effect on Central Nervous System

1.1 General observation on native behavior

Three male NMRI mice/dose were adminis- 
tered CHLORIDAZON TECH orally at dose levels of 0,500 and $1000 \mathrm{mg} / \mathrm{kg}$ b.w.

The test substance caused passivity, ptosis and auxicity. In the high dose group, tonicclonic convulsions were observed. The animals were frightened.

\subsection{Prolongation of sleeping time induced by hexobarbitone}

Six male NMRI mice/dose were administered CHLORIDAZON TECH orally at dose levels of 0,500 and $1000 \mathrm{mg} / \mathrm{kg} \mathrm{b.w}$. One hour after administration, $70 \mathrm{mg} / \mathrm{kg}$ b.w. hexobarbitone were injected intraperitoneally, and then the sleeping time was measured.

No effect was observed on hexobarbitone induced sleeping time.

\subsection{Effect on convulsion induced by pentetrazole or strychnine}

Six male NMRI mice/dose were administered CHLORIDAZON TECH orally at dose levels of 0,500 and $1000 \mathrm{mg} / \mathrm{kg}$ b.w. One hour after the administration, $150 \mathrm{mg} / \mathrm{kg}$ b.w. pentetrazole or $2 \mathrm{mg} / \mathrm{kg}$ b.w. strychnine were injected intraperitoneally. The time until the convulsions appeared was measured and the mortality was recorded.

No significant effect was observed on convulsion onset and mortality induced by pentetrazole or strychnine.

\subsection{Effect on body temperature}

CHLORIDAZON TECH was administered orally to Wistar rats, 6 males/dose, at dose levels of 0,500 and $1000 \mathrm{mg} / \mathrm{kg} \mathrm{b.w}$. and to New Zealand White rabbits, 5 males/dose, at a dose level of $1000 \mathrm{mg} / \mathrm{kg}$ b.w. The rectal temperature was recorded every hour.

In rats, a dose-related decrease of the body temperature was observed, whereas the administration of the test substance had no effect on body temperature in rabbits.

\subsection{Effect on locomotor activity}

Six male NMRI mice/dose were administered CHLORIDAZON TECH orally at dose levels of 0,500 and $1000 \mathrm{mg} / \mathrm{kg}$ b.w., and locomotor activity was recorded at a certain time interval.

A slight depressing effect on the locomotor activity was observed at the low dose, whereas $1000 \mathrm{mg} / \mathrm{kg}$ Chloridazon had a strong depressing effect on the locomotor activity.

\subsection{Effect on electroencephalogram (EEG)}

Two male SD rats/dose were orally administered CHLORIDAZON TECH at dose levels of $0,316,681$ and $1000 \mathrm{mg} / \mathrm{kg}$ b.w. The EEG was recorded for $400-480$ minutes post administration.

No pathological signs in the EEG were observed. The test substance caused a dosedependent prolongation of the waking phase in the EEG without simultaneously stimulating motor activity. In two high dose groups, shaggy hair, ataxia, tremor, sterotyped chewing movements and muscle twitching were observed, which were more marked and longer lasting in the highest group than the mid dose group.

\section{Effect on Autonomic Nervous System and Smooth Muscle}

\subsection{Effects on isolated ileum}

Specimens of the ileum of 2 guinea pigs were prepared and suspended in organ bath solution. After obtaining constant concentrationresponse curves for acetylcholine and histamine by their cumulative application, CHLORIDAZON TECH was applied to the bath.

The test substance had an acetylcholine-like effect on the isolated ileum, which was inhibited by atropine. Furthermore, the test substance inhibited histamine-induced contractions.

\subsection{Effects on isolated vas deferens}

Vas deferentia was prepared from 4 male guinea pigs and then suspended in organ bath. After obtaining constant concentration-response curves for acetylcholine and epinephrine by their cumulative application, CHLORIDAZON TECH was applied to the bath.

The test substance had only slight effects on acetylcholine-induced contractions, whereas epinephrine-induced contractions were inhibited.

\subsection{Effects on isolated trachea}

Trachea segments were prepared from 6 male guinea pigs and suspended in organ bath. After obtaining constant concentration-response curves for acetylcholine, histamine and epinephrine by their cumulative application, CHLORIDAZON TECH was applied to the organ bath.

The test substance had very slight effects on 
acetylcholine-induced contractions at low concentrations, but a decreased contractile response at high concentrations. At high concentrations, the contractile response of histamine and epinephrine was inhibited.

\section{Effect on Blood Pressure, Heart Rate and Respiration}

Three male New Zealand White rabbits/dose were used for the test. CHLORIDAZON TECH was intraperitoneally injected at a dose level of $500 \mathrm{mg} / \mathrm{kg}$ b.w.

The test substance did not affect blood pressure, heart rate, respiratory rate and standardized (agonists: histamine, acetylcholine, norepinephrine) blood pressure responses.

\section{Effect on Digestive System}

4.1 Effect on intestinal motility-charcoal propulsion

Subcutaneous application of 0 and 2000 $\mathrm{mg} / \mathrm{kg}$ b.w. CHLORIDAZON TECH to 10 male NMRI mice/dose inhibited the intestinal motility by $37.5 \%$.

\subsection{Effect on gastric secretion}

Five male Wistar rats/dose were administered CHLORIDAZON TECH orally at dose levels of 0,500 and $1000 \mathrm{mg} / \mathrm{kg}$ b.w. Removing the stomach after clamping the cardiac orifice, the gastric juice was collected to measure the volume and $\mathrm{pH}$.

The test substance did not influence the gastric secretion.

\section{Effect on Skeletal Muscle}

CHLORIDAZON TECH intraperitoneally applicated to 4 male Wistar rats/dose at a dose level of $250 \mathrm{mg} / \mathrm{kg}$ b.w. had no effect on skeletal muscle and mean blood pressure.

\section{Effect on Blood}

\subsection{Effect on blood coagulation}

Seven male Wistar rats/dose were administered CHLORIDAZON TECH orally at dose levels of 0,500 and $1000 \mathrm{mg} / \mathrm{kg}$ b.w. Taking the blood from the retro-orbital plexus after the administration, PT, PTT and TT were measured.

The test substance had no effects on blood coagulation parameters.

\subsection{Effect on hemolysis}

From 2 male New Zealand White rabbits, blood was taken and collected in heparinized tubes. To the erythrocyte suspension, CHLORIDAZON TECH solutions in concentrations of $0.1,1$ and $10 \%$ were added.

A $10 \%$ test substance suspension caused a moderate hemolysis on a $5 \%$ in vitro erythrocyte suspension two hours after incubation.

(Research \& Consulting Company AG, 1987, and Knoll AG, 1988)

According to the results of the pharmacological studies, it is considered that Chloridazon has direct effects on the motoric brain centers and the autonomic nervous system. Possible intoxication by oral route may be treated with atropine and a hypnotic.

\section{SUMMARY}

In order to investigate toxicological properties of Chloridazon, a number of toxicological studies were carried out with CHLORIDAZON TECH and/or PYRAMIN WP. From these studies, it can be derived that the acute toxicity, subacute toxicity, and long-term toxicity are rather low. Weak or moderate irritant effects on eye and skin were noted, but no skin sensitizing effect was observed. Inhalation risk can be excluded under practical conditions. No adverse effects were observed on reproduction parameters, and no signs of teratogenic effects were noted. Chloridazon was investigated for mutagenic properties in various studies, all three end points of genetic damage covered. In view of these results, Chloridazon can be assessed as not mutagenic. There were no signs of an oncogenic response in any of the tested animals.

Withholding values have been set for the registration at $0.1 \mathrm{ppm}$ each on sugar beet and vegetables since April, 1976.

A safety risk for Chloridazon is not to be expected as far as it is used in accordance with the established safe use standard.

\section{Contact}

Registration Department, Agricultural Chemicals Division, BASF Japan Ltd.

3-3, Kioicho, Chiyoda-ku, Tokyo 102, Japan 問合せ

ビーエーエスエフジャパン株式会社農薬部登録課

干102 東京都千代田区紀尾井町 3-3 